\title{
Growth, Productivity and Economics of Kabuli Chickpea (Cicer arietinum L.) Genotypes in Response to Seed Rate in Northern India
}

\author{
Guriqbal Singh*, Hari Ram and Navneet Aggarwal \\ Department of Plant Breeding and Genetics, Punjab Agricultural University, \\ Ludhiana 141004, India \\ *Corresponding author
}

\begin{tabular}{|c|c|}
\hline \multicolumn{2}{|r|}{ A B S T R A C T } \\
\hline & \multirow{5}{*}{$\begin{array}{l}\text { Seed is a basic and costly input in agriculture. Genotypes of a crop varying in seed } \\
\text { size and growth behaviour may differ in optimal seed rate for realizing high grain } \\
\text { yields. Field experiments were conducted for three years at Punjab Agricultural } \\
\text { University, Ludhiana, India to study the growth, productivity and economics of } \\
\text { kabuli chickpea genotypes in response to seeding rate. On the basis of three-year } \\
\text { mean, seeding rate of } 110 \mathrm{~kg} \mathrm{ha}^{-1} \text { provided the highest grain yield }\left(1491 \mathrm{~kg} \mathrm{ha}^{-1}\right) \text {, } \\
\text { followed by } 130 \mathrm{~kg} \mathrm{ha}^{-1}\left(1415 \mathrm{~kg} \mathrm{ha}^{-1}\right) \text { and } 90 \mathrm{~kg} \mathrm{ha}^{-1} \text { seed rate }\left(1196 \mathrm{~kg} \mathrm{ha}^{-1}\right) \text {. } \\
\text { Among genotypes, BG } 1053 \text {, GLK } 22117 \text {, GLK } 24092 \text { and GLK } 25132 \mathrm{were} \mathrm{high} \\
\text { yielders. Higher grain yields were produced by BG } 1053 \text {, GLK } 22117 \text {, GLK } \\
24092 \text { and GLK } 25132 \text { with a seed rate of } 110 \mathrm{~kg} \mathrm{ha}^{-1} \text {, whereas GLK } 23008 \text { and } \\
\text { GLK } 23035 \text { yielded higher at } 130 \mathrm{~kg} \mathrm{ha}^{-1} \text { seed rate. A seed rate of } 110 \mathrm{~kg} \mathrm{ha}^{-1} \\
\text { provided with the highest gross returns, net returns and B:C ratio. Genotypes } \\
\text { differed in days to } 50 \% \text { flowering (88-110 days) and days to maturity (136-163 } \\
\text { days). }\end{array}$} \\
\hline Keywords & \\
\hline $\begin{array}{l}\text { Chickpea, } \\
\text { Phenology, Plant } \\
\text { population, Net } \\
\text { returns, Seed rate. }\end{array}$ & \\
\hline Article Info & \\
\hline & \\
\hline
\end{tabular}

\section{Introduction}

Chickpea (Cicer arietinum L.) is an important grain legume in the world. During 2014, globally it was grown on 13.98 million ha area, with the total production of 13.73 million tonnes (FAOSTAT, 2017) and average productivity of $982 \mathrm{~kg} \mathrm{ha}^{-1}$. The important chickpea growing countries are India, Turkey, Pakistan, Australia, Myanmar and Ethiopia. In many countries, the average chickpea yields are very low. Many biotic and abiotic constraints limit chickpea yield (Sekhon et al., 1994, 2002, 2004; Virk et al., 2005; Singh et al., 2011, 2016; Sharma and Singh, 2013; Singh, 2016). Major biotic constraints include Ascochyta blight caused by Ascochyta rabiei, Botrytis grey mould caused by Botrytis cinerea and gram pod borer Heliothis armigera whereas major abiotic factors are very low as well as very high temperatures, moisture stress, salinity etc.

Kabuli chickpea is one of the two types of chickpea (desi and kabuli) which has creamcoloured large seed with a thin seed coat, in contrast to desi type which has darkercoloured small-sized seed with a thick seed coat. In kabuli chickpea, a plant population of 
40-45 plants $\mathrm{m}^{-2}$ provides high grain yields (Gan et al., 2003b). Inadequate plant population is one of the important factors responsible for poor grain yields of chickpea (Nagarajaiah et al., 2005; Bavalgave et al., 2009). Poor plant stand could be due to use of low seed rate, poor quality seed, insufficient moisture at sowing, plant mortality due to various diseases or salinity or moisture stress, etc. Adequate plant population may be maintained by using good quality optimum seed rate. However, seed is a costly input and need to be used judiciously as it involves lot of money. Further, as chickpea is generally grown under one or the other stress conditions on marginal soils, the risk of the crop failure discourages farmers to use costly inputs including the use of high seed rate.

Rice (Oryza sativa)-wheat (Triticum aestivum) is an important cropping system in northern India, especially in the states of Punjab, Haryana and Western Uttar Pradesh. Though this cropping system proved to be very good in terms of high yields, ensuring food security and high income to the farmers yet it has its own demerits including the lowering of ground water table (Hira, 2009). Underground water has to be used judiciously for sustaining crop production. Diversifying rice-wheat cropping system with some less water requiring crops is the need of the day. At present levels of the yields and prices offered, no other crop than rice can be taken by the farmers as rice is a stable crop, with high yield levels, good minimum support price and no difficulty in procurement by the government and other agencies. So replacement of rice with any other crop during the rainy (kharif) season seems to be difficult. However, during winter (rabi) season kabuli chickpea has the potential to provide with the high income to farmers due to its good price in the market and, therefore, it could replace some area under wheat. Kabuli chickpea has lower water requirement than wheat and it is used by the people in a variety of forms in their diet.

The optimum seed rate for desi chickpea genotypes is $45 \mathrm{~kg} \mathrm{ha}^{-1}$ whereas for kabuli types it is $92.5 \mathrm{~kg} \mathrm{ha}^{-1}$ (PAU, 2016). Further, seed rate requirement varies with the seed size (Singh and Sekhon 2006; Sekhon and Singh, 2008; Sheoran et al., 2008). Bold seeded kabuli chickpeas are used for table purpose. Therefore, there is a need to develop bold seeded kabuli chickpea genotypes. As these bold seeded genotypes may require high seed rate for high yields, there was a need to study their optimum seed rate requirements. Experiments were, therefore, conducted to study the response of kabuli chickpea genotypes to seed rate.

\section{Materials and Methods}

\section{Site characterization}

The experiments were conducted during winter (rabi) season in 2005-06, 2006-07 and 2007-08 at Punjab Agricultural University, Ludhiana, India. Ludhiana is situated at $30^{\circ} 56^{\prime} \mathrm{N}, 72^{\circ} 52^{\prime} \mathrm{E}$, altitude $247 \mathrm{~m}$. The soil of the experimental site was loamy sand, having $\mathrm{pH}$ 8.2, testing low in organic carbon $(0.30 \%)$, medium in available phosphorus $(15.2 \mathrm{~kg} / \mathrm{ha})$, and medium in available potash $(225.5 \mathrm{~kg} / \mathrm{ha})$. The weekly mean minimum and maximum temperatures recorded at the Meteorological Observatory of the Punjab Agricultural University, Ludhiana, India are presented in figure 1 and weekly total rainfall data recorded during the crop growing period are presented in table 1 . The minimum weekly mean temperature was very low from standard week 50 (mid December) to standard week 7 (mid February) during all the three years of the study and it was the lowest during 2007-08 especially during standard week 4 to 7. The maximum weekly mean temperature was quite high during standard week 15-18 
(mid to end April). Rainfall during the crop season was higher in 2006-07 than in 2005-06 and 2007-08.

\section{Treatments and experimental design}

Field experiments comprising three/four genotypes (BG 1053, GLK 21143 and GLK 22117 in 2005-06, BG 1053, GLK 22117, GLK 23008 and GLK 23035 in 2006-07 and BG 1053, GLK 24092 and GLK 25132 in 2007-08) and three seed rates (90, 110 and $130 \mathrm{~kg} \mathrm{ha}^{-1}$ ) were conducted in a factorial randomized block design. The genotypes used in the present studies varied in seed size and phenology, as discussed in Results section.

\section{Crop husbandry}

Brief crop husbandry details are given in table 2. The pre-sowing irrigations were applied and at optimum moisture the seed bed was prepared by 2-3 cultivations followed by planking. The sowing was done in rows 30 $\mathrm{cm}$ apart and at about $5 \mathrm{~cm}$ depth with the drill manually. Total rainfall of 54.4, 284.5 and $87.5 \mathrm{~mm}$ was received during the crop season in 2005-06, 2006-07 and 2007-08, respectively. Irrigation was applied as per the need of the crop. Weeds were controlled by spraying a pre-emergence herbicide Stomp 30 EC (pendmethalin)@ $2.51 \mathrm{ha}^{-1}$ with a knap sack sprayer fitted with flood jet nozzle using 500 litres of water ha ${ }^{-1}$. Afterwards, weeds were removed by hand weeding wherever necessary. Protective spray of Captaf was done in the month of March against Ascochyta blight. Two sprays were done with insecticides in March-April every year against gram pod borer (Heliothis armigera).

\section{Observations recorded}

Data on days to $50 \%$ flowering (when at least one open flower was observed on about $50 \%$ plants in the plot) and maturity were recorded for all the genotypes. At maturity, data on plant height, primary branches plant $^{-1}$, secondary branches plant ${ }^{-1}$, pods plant ${ }^{-1}$, seeds pod $^{-1}$, 100-seed weight were recorded. Grain yield and biological yield data were recorded on whole plot basis and then converted to $\mathrm{kg}$ $\mathrm{ha}^{-1}$. Harvesting and threshing were done manually. Harvest index was calculated by dividing grain yield by biological yield and then multiplying by 100 . Gross returns, net returns and benefit:cost ratio were also worked out.

\section{Statistical analysis}

All data except days to $50 \%$ flowering and maturity were subjected to analysis of variance in a factorial randomized block design as per the standard procedure. Wherever the ' $F$ ' ratio was significant, the critical difference (CD) values were calculated at $5 \%$ level of significance.

\section{Results and Discussion}

\section{Weather}

The weekly minimum and maximum temperatures experienced by the crop and the rainfall received during the crop season are presented in figure 1. At sowing and emergence, the maximum temperature varied between $22^{\circ} \mathrm{C}$ and $29^{\circ} \mathrm{C}$ and the minimum temperature was $7^{\circ} \mathrm{C}$ to $13^{\circ} \mathrm{C}$. During the months of December and January, both maximum and minimum temperatures dropped. During these two months the minimum temperature varied between $3.1^{\circ} \mathrm{C}$ and $10.3^{\circ} \mathrm{C}$ in $2005-06,1.8^{\circ} \mathrm{C}$ and $9.6^{\circ} \mathrm{C}$ in 2006-07 and $0.9^{\circ} \mathrm{C}$ and $10.7^{\circ} \mathrm{C}$ in 2007-08. In the months of March and April, the temperatures raised and the maximum weekly temperature was more than $35^{\circ} \mathrm{C}$ in some weeks in April.

\section{Performance of genotypes}

In 2005-06, GLK 22117 and GLK 21143 were on par in plant height and both were 
significantly taller than BG 1053 (Table 3). However, BG 1053 had significantly higher number of secondary branches plant ${ }^{-1}$ and pods plant ${ }^{-1}$ than the other two genotypes. Primary branches plant ${ }^{-1}$ and seeds pod ${ }^{-1}$ were similar in all the three genotypes. GLK 22117 had the highest 100-seed weight of $36.0 \mathrm{~g}$ whereas GLK 21143 and BG 1053 had 100seed weight of 34.7 and $32.4 \mathrm{~g}$, respectively. BG 1053 was significantly superior to GLK 22117 and GLK 21143 in grain yield. GLK 21143 was the lowest in grain as well as biological yield.

In 2006-07, GLK 22117 and GLK 23008 registered higher plant height but lower secondary branches plant ${ }^{-1}$ than BG 1053 and GLK 23035 (Table 4). Primary branches plant $^{-1}$ and pods plant ${ }^{-1}$ were not significantly influenced by genotypes. GLK 23035 had lowest seeds pod $^{-1}$ but highest 100-seed weight. GLK 22117 yielded grains significantly higher than GLK 23008 and GLK 23035 but was on par with BG 1053. All genotypes were on par in biological yield.

In 2007-08, GLK 24092 produced tallest plants (Table 5), BG 1053 had highest seeds pod $^{-1}$ and GLK 25132 had highest 100-seed weight. Primary branches plant ${ }^{-1}$, secondary branches plant ${ }^{-1}$ and pods plant ${ }^{-1}$ were not influenced significantly. GLK 24092 recorded significantly higher grain yield than GLK 25132 but it was on par with BG 1053. Genotypes did not differ in biological yield.

\section{Effect of seed rate}

In 2005-06, highest plant height and primary branches plant ${ }^{-1}$ were recorded in case of 130 $\mathrm{kg} \mathrm{ha}^{-1}$ seed rate (Table 3), highest secondary branches plant ${ }^{-1}$ and pods plant ${ }^{-1}$ with $90 \mathrm{~kg}$ ha $^{-1}$ seed rate, and highest 100 -seed weight, grain yield and biological yield with $110 \mathrm{~kg}$ $\mathrm{ha}^{-1}$ seed rate.
In 2006-07, a seed rate of $130 \mathrm{~kg} \mathrm{ha}^{-1}$ produced tallest plants and highest grain as well as biological yields. Other plant growth and yield attributes were not influenced significantly.

In 2007-08, highest plant height was recorded with a seed rate of $130 \mathrm{kgha}^{-1}$ whereas maximum pods plant ${ }^{-1}$ and grain yield were registered with $110 \mathrm{kgha}^{-1}$ seed rate. Other plant growth, yield attributes and biological yield were not influenced significantly.

\section{Genotypes $\times$ Seed rate interaction effect}

The genotypes $x$ seed rate interaction was significant with respect to the grain yield in 2005-06 and 2006-07 (Table 6). In 2005-06, highest grain yield was produced by BG 1053 with $110 \mathrm{~kg} \mathrm{ha}^{-1}$ seed rate $\left(1667 \mathrm{~kg} \mathrm{ha}^{-1}\right)$, which was significantly higher than the grain yields produced by other genotypes at all three seed rates. In 2006-07, GLK 22117 with $110 \mathrm{~kg} \mathrm{ha}^{-1}$ seed rate produced the highest grain yield $\left(1385 \mathrm{~kg} \mathrm{ha}^{-1}\right)$, which was, however, on par with grain yields produced by BG 1053 with 90 and $110 \mathrm{~kg} \mathrm{ha}^{-1}$ seed rate (1244 and $1320 \mathrm{~kg} \mathrm{ha}^{-1}$ ), GLK 22117 with 90 and $130 \mathrm{~kg} \mathrm{ha}^{-1}$ seed rate $(1287$ and $1244 \mathrm{~kg}$ $\mathrm{ha}^{-1}$ ) and GLK 23035 with $130 \mathrm{~kg} \mathrm{ha}^{-1}$ seed rate $\left(1277 \mathrm{~kg} \mathrm{ha}^{-1}\right)$. In 2007-08, all three genotypes produced higher grain yields with 110 and $130 \mathrm{~kg} \mathrm{ha}^{-1}$ than $90 \mathrm{~kg} \mathrm{ha}^{-1}$ seed rate.

\section{Economics}

Genotype BG 1053 in 2005-06, GLK 22117 in 2006-07 and GLK 24092 in 2007-08 provided the highest gross returns (Table 7), net returns (Table 8) and B:C ratio (Table 9). On the basis of three-year mean, a seed rate of $110 \mathrm{~kg} \mathrm{ha}^{-1}$ provided the highest gross as well as net returns followed by seed rate of $130 \mathrm{~kg}$ $\mathrm{ha}^{-1}$ whereas B:C ratio was the highest with seed rate of $110 \mathrm{~kg} \mathrm{ha}^{-1}$ followed by 90 and $130 \mathrm{~kg} \mathrm{ha}^{-1}$ seed rates. 


\section{Phenology}

Time taken to $50 \%$ flowering and maturity varied with the genotypes and years (Table 10). In general, time taken to $50 \%$ flowering was shortest (88-95 days) in 2005-06 whereas time to maturity was shortest in 2007-08 (136-144 days). Time taken to 50\% flowering (106-110 days) as well as maturity (156-163 days) was longest in 2006-07.

Chickpea is an important grain legume having protein-rich grains. Two types of chickpeas desi and kabuli are grown. Kabuli types have higher market price, which provides farmers with higher income. Seed is a basic and costly input in agriculture. Use of optimum seed rate is essential for maintaining adequate plant population and consequently for obtaining higher grain yields. On mean basis, compared with $90 \mathrm{~kg} \mathrm{ha}^{-1}$ seed rate, seed rates of 110 and $130 \mathrm{~kg} \mathrm{ha}^{-1}$ produced $+10.42 \%$ and $1.84 \%$ yields in $2005-06,+12.05 \%$ and $+12.61 \%$ in $2006-07$ and $+52.47 \%$ and $+46.76 \%$ in $2007-08$. On the basis of three years average, $24.66 \%$ and $18.31 \%$ higher grain yields were obtained with 110 and 130 $\mathrm{kg} \mathrm{ha}^{-1}$ seed rate over $90 \mathrm{~kg} \mathrm{ha}^{-1}$. Grain yield in chickpea is influenced greatly with seed rate (Venkatachalapathi and Saini, 2003; Nagarajaiah et al., 2005; Kumar et al., 2008; Kumar et al., 2009).

Plant height was highest with the highest seed rate of $130 \mathrm{~kg} \mathrm{ha}^{-1}$ in all the three years (Tables 3, 4 and 5), which could be due to competition amongst the plants for sunlight. As the seed rate increased, pods plant ${ }^{-1}$ decreased in 2005-06 (Table 3) and 2006-07 (Table 4) as also reported by other researchers (Khan et al., 1999; Venkatachalapathi et al., 2004; Choudhary et al., 2005), which could be due to competition amongst the plants for nutrients and moisture. The 100-seed weight was not influenced due to seed rates in 200607 and 2007-08 (Tables 4 and 5) as generally it is not influenced by environment, as reported by other researchers also (Mansur $e t$ al., 2009).

High grain yields obtained with the use of 110 $\mathrm{kg} \mathrm{ha}^{-1}$ seed rate (Tables 3-5) could be due to reasonably good number of pods plant ${ }^{-1}$, seeds pod $^{-1}$ and 100 -seed weight. Though pods plant $^{-1}$ decreased with the increase in seed rate, higher grain yields obtained with 100 and $130 \mathrm{~kg} \mathrm{ha}^{-1}$ over $90 \mathrm{~kg} \mathrm{ha}^{-1}$ seed rate (except in 2005-06) could be due to higher number of pods per unit area owing to increased plant populations. Grain yields in chickpea are strongly and positively correlated with the number of pods and seeds $\mathrm{m}^{-2}$ (Gan et al., 2003c; Ayaz et al., 2004b). With increased plant population, the green area index, intercepted radiation, radiation use efficiency and total intercepted photosynthetically active radiation increase (Ayaz et al., 2004c), thereby resulting in higher grain yields. Biological yield increased with an increase in seed rate (except in 200506), which may be the result of increased plant population. Biological yield is known to increase with increased plant population (Ayaz et al., 2004a). Quite good grain and biological yields with $90 \mathrm{~kg} \mathrm{ha}^{-1}$ seed rate in 2005-06 may be due to favourable weather conditions (Figure 1) for plant growth.

Seed rates influenced gross returns (Table 7) and net returns (Table 8), which, on the basis of three-year mean, were the highest with a seed rate of $110 \mathrm{~kg} \mathrm{ha}^{-1}$, followed by $130 \mathrm{~kg}$ $\mathrm{ha}^{-1}$ and $90 \mathrm{~kg} \mathrm{ha}^{-1}$. The trend in returns with different seed rates was the same as for grain yield. Other researchers also reported variation in returns with different seed rates (Choudhary et al., 2005; Nagarajaiah et al., 2005; Kumar et al., 2009). The B:C ratio was the highest with a seed rate of $110 \mathrm{~kg} \mathrm{ha}^{-1}$ and, unlike grain yield or gross and net returns, was lower with $130 \mathrm{~kg}$ than $90 \mathrm{~kg}$ ha ${ }^{1}$ seed rate as the use of the highest seed rate 
also involved higher cost and the gain in grain yield was not that much which could compensate the cost involved.

Seed rate influenced harvest index slightly in 2005-06 and 2006-07 but more so in 2007-08. Harvest index was higher in 2007-08 (Table 5) than in 2005-06 (Table 3) and 2006-07 (Table 4). Biological yield was low in 200708, which could be due to restricted plant growth during the months of December, January and February owing to very low minimum temperature (Figure 1) and frost occurrence. This checked over vegetation growth and consequently favoured better source-sink relationship. Grain yields were generally lower in 2006-07 than in 2005-06 and 2007-08, which could be due to, apart from different genotypes, variation in temperatures (Figure 1) and rainfall (Table 1).
Other researchers have also reported large year-to-year variation in chickpea grain yields (Kibe and Kamithi, 2007).

Among genotypes, BG 1053, GLK 22117, GLK 24092 and GLK 25132 were the high yielders. These genotypes produced higher grain yields due to higher number of pods plant $^{-1}$, seeds pod ${ }^{-1}$ and/or higher 100-seed weight. Genotypes of chickpea do differ in productivity (Sekhon et al., 2001; Nagarajaiah et al., 2005; Bavalgave et al., 2009; Aggarwal et al., 2016). Maturity duration differed with genotype and year (Table 10). In northern India, chickpea experiences sudden rise in temperature near maturity, which adversely affects grain development and consequently grain yield. Therefore, genotypes with shorter duration may help in avoiding high temperature induced reduction in the yield.

Table.1 Total monthly rainfall received during the crop growing season in 2005-06, 2006-07 and 2007-08

\begin{tabular}{lccc}
\hline Month & \multicolumn{3}{c}{ Rainfall received $(\mathrm{mm})$} \\
\cline { 2 - 4 } & $2005-06$ & $2006-07$ & $2007-08$ \\
\hline November & 0.0 & 14.0 & 1.3 \\
December & 0.0 & 22.7 & 17.7 \\
January & 16.8 & 10.0 & 16.3 \\
February & 0.0 & 85.6 & 2.0 \\
March & 32.5 & 126.0 & 0.0 \\
April & 5.1 & 26.2 & 50.2 \\
\hline Total & 54.4 & 284.5 & 87.5 \\
\hline
\end{tabular}

Table.2 Treatments and crop husbandry details of three years of the study

\begin{tabular}{llll}
\hline Particulars & 2005-06 & 2006-07 & 2007-08 \\
\hline Genotypes & BG 1053, GLK 21143 & BG 1053, GLK & BG 1053, GLK \\
& and GLK 22117 & $\begin{array}{l}\text { 22117, GLK 23008 } \\
\text { and GLK 23035 }\end{array}$ & GLO2 25132 \\
& & 90,110 and 130 & 90,110 and 130 \\
Seed rates $\left(\mathrm{kg} \mathrm{ha}^{-1}\right)$ & 90,110 and 130 & Factorial RBD & Factorial RBD \\
$\begin{array}{l}\text { Design } \\
\text { Replications }\end{array}$ & Factorial RBD & 4 & 3 \\
Date of sowing & 11 November 2005 & 11 November 2006 & 14 November 2007 \\
Date of harvesting & 29 April 2006 & 25 April 2007 & 28 April 2008 \\
\hline
\end{tabular}


Table.3 Effect of genotypes and seed rate on plant traits and grain yield of kabuli chickpea in 2005-06

\begin{tabular}{|c|c|c|c|c|c|c|c|c|c|}
\hline Treatment & $\begin{array}{l}\text { Plant } \\
\text { height } \\
(\mathrm{cm})\end{array}$ & $\begin{array}{c}\text { Primary } \\
\text { branches plant }^{-1}\end{array}$ & $\begin{array}{c}\text { Secondary } \\
\text { branches plant }^{-1}\end{array}$ & $\begin{array}{l}\text { Pods } \\
\text { plant }^{-1}\end{array}$ & $\begin{array}{l}\text { Seeds } \\
\operatorname{pod}^{-1}\end{array}$ & $\begin{array}{c}\text { 100-seed } \\
\text { weight } \\
(\mathrm{g})\end{array}$ & $\begin{array}{l}\text { Grain yield } \\
\left(\mathrm{kg} \mathrm{ha}^{-1}\right)\end{array}$ & $\begin{array}{c}\text { Biological } \\
\text { yield (kg } \\
\left.\text { ha }^{-1}\right)\end{array}$ & $\begin{array}{c}\text { Harvest } \\
\text { index } \\
(\%)\end{array}$ \\
\hline \multicolumn{10}{|l|}{ Genotype } \\
\hline BG 1053 & 39.6 & 4.43 & 10.40 & 30.1 & 1.28 & 32.4 & 1529 & 4320 & 35.39 \\
\hline GLK 21143 & 44.9 & 4.47 & 8.30 & 24.0 & 1.28 & 34.7 & 1227 & 3803 & 32.26 \\
\hline GLK 22117 & 46.3 & 4.23 & 9.80 & 22.8 & 1.23 & 36.0 & 1419 & 4355 & 32.58 \\
\hline CD $5 \%$ & 1.8 & NS & 0.50 & 2.1 & NS & 0.8 & 85 & 258 & \\
\hline \multicolumn{10}{|c|}{ Seed rate $\left(\mathrm{kg} \mathrm{ha}^{-1}\right)$} \\
\hline 90 & 42.1 & 4.03 & 10.40 & 27.7 & 1.32 & 33.6 & 1353 & 4196 & 32.24 \\
\hline 110 & 43.3 & 4.38 & 8.80 & 26.7 & 1.24 & 35.2 & 1494 & 4334 & 34.47 \\
\hline 130 & 45.4 & 4.72 & 9.30 & 22.5 & 1.23 & 34.4 & 1328 & 3948 & 33.63 \\
\hline CD 5\% & 1.8 & 0.20 & 0.50 & 2.1 & NS & 0.8 & 85 & 258 & \\
\hline
\end{tabular}

Table.4 Effect of genotypes and seed rate on plant traits and grain yield of kabuli chickpea in 2006-07

\begin{tabular}{|c|c|c|c|c|c|c|c|c|c|}
\hline Treatment & $\begin{array}{l}\text { Plant } \\
\text { height } \\
(\mathrm{cm})\end{array}$ & $\begin{array}{c}\text { Primary } \\
\text { branches plant }^{-1}\end{array}$ & $\begin{array}{c}\text { Secondary } \\
\text { branches plant }^{-1}\end{array}$ & $\begin{array}{l}\text { Pods } \\
\text { plant }^{-1}\end{array}$ & $\begin{array}{l}\text { Seeds } \\
\operatorname{pod}^{-1}\end{array}$ & $\begin{array}{c}\text { 100-seed } \\
\text { weight } \\
(\mathrm{g})\end{array}$ & $\begin{array}{c}\text { Grain yield } \\
\left(\mathrm{kg} \mathrm{ha}^{-1}\right)\end{array}$ & $\begin{array}{c}\text { Biological } \\
\text { yield (kg } \\
\left.\mathrm{ha}^{-1}\right)\end{array}$ & $\begin{array}{c}\text { Harvest } \\
\text { index } \\
(\%)\end{array}$ \\
\hline \multicolumn{10}{|l|}{ Genotype } \\
\hline BG 1053 & 50.9 & 1.96 & 5.43 & 25.2 & 1.40 & 29.8 & 1241 & 4329 & 28.66 \\
\hline GLK 22117 & 56.5 & 1.98 & 5.00 & 23.6 & 1.36 & 32.2 & 1306 & 4581 & 28.50 \\
\hline GLK 23008 & 55.7 & 1.96 & 5.05 & 24.7 & 1.31 & 33.0 & 997 & 4264 & 23.38 \\
\hline GLK 23035 & 52.7 & 2.10 & 5.31 & 23.0 & 1.20 & 36.4 & 1053 & 4242 & 24.82 \\
\hline CD $5 \%$ & 2.3 & NS & 0.34 & NS & 0.11 & 0.4 & 90 & NS & \\
\hline \multicolumn{10}{|c|}{ Seed rate $\left(k g h a^{-1}\right)$} \\
\hline 90 & 50.6 & 1.97 & 5.32 & 24.7 & 1.31 & 32.8 & 1062 & 4036 & 26.31 \\
\hline 110 & 54.6 & 2.03 & 5.21 & 24.6 & 1.31 & 32.8 & 1190 & 4426 & 26.88 \\
\hline 130 & 56.7 & 2.00 & 5.06 & 23.2 & 1.32 & 32.9 & 1196 & 4599 & 26.00 \\
\hline CD $5 \%$ & 2.0 & NS & NS & NS & NS & NS & 78 & 256 & \\
\hline
\end{tabular}


Int.J.Curr.Microbiol.App.Sci (2017) 6(7): 3917-3930

Table.5 Effect of genotypes and seed rate on plant traits and grain yield of kabuli chickpea in 2007-08

\begin{tabular}{|c|c|c|c|c|c|c|c|c|c|}
\hline Treatment & $\begin{array}{l}\text { Plant } \\
\text { height } \\
(\mathrm{cm})\end{array}$ & $\begin{array}{c}\text { Primary } \\
\text { branches plant }^{-1}\end{array}$ & $\begin{array}{c}\text { Secondary } \\
\text { branches plant }^{-1}\end{array}$ & $\begin{array}{l}\text { Pods } \\
\text { plant }^{-1}\end{array}$ & $\begin{array}{l}\text { Seeds } \\
\operatorname{pod}^{-1}\end{array}$ & $\begin{array}{c}\text { 100-seed } \\
\text { weight } \\
(\mathrm{g})\end{array}$ & $\begin{array}{c}\text { Grain } \\
\text { yield (kg } \\
\left.\mathrm{ha}^{-1}\right)\end{array}$ & $\begin{array}{c}\text { Biological } \\
\text { yield (kg } \\
\left.\mathrm{ha}^{-1}\right)\end{array}$ & $\begin{array}{c}\text { Harvest } \\
\text { index } \\
(\%)\end{array}$ \\
\hline \multicolumn{10}{|l|}{ Genotype } \\
\hline BG 1053 & 44.8 & 4.09 & 6.84 & 26.1 & 1.64 & 28.2 & 1549 & 4156 & 37.27 \\
\hline GLK 24092 & 52.3 & 3.87 & 5.89 & 24.0 & 1.38 & 33.9 & 1692 & 3981 & 42.50 \\
\hline GLK 25132 & 45.5 & 4.13 & 6.92 & 21.6 & 1.51 & 36.8 & 1446 & 3539 & 40.85 \\
\hline CD 5\% & 2.0 & NS & NS & NS & 0.17 & 0.4 & 169 & NS & \\
\hline \multicolumn{10}{|c|}{ Seed rate $\left(\mathrm{kg} \mathrm{ha}^{-1}\right)$} \\
\hline 90 & 45.8 & 3.82 & 7.04 & 21.6 & 1.53 & 33.0 & 1174 & 3426 & 34.26 \\
\hline 110 & 47.8 & 4.04 & 6.42 & 27.6 & 1.53 & 33.0 & 1790 & 4064 & 44.04 \\
\hline 130 & 49.0 & 4.22 & 6.19 & 22.5 & 1.47 & 33.0 & 1723 & 4187 & 41.15 \\
\hline CD $5 \%$ & 2.0 & NS & NS & 4.1 & NS & NS & 169 & NS & \\
\hline
\end{tabular}


Table.6 Grain yield of kabuli chickpea genotypes as influenced by seed rates

\begin{tabular}{|c|c|c|c|c|c|}
\hline \multirow[t]{3}{*}{ Year } & \multirow[t]{3}{*}{ Genotype } & \multirow{2}{*}{\multicolumn{3}{|c|}{$\begin{array}{c}\text { Grain yield }\left(\mathrm{kg} \mathrm{ha}^{-1}\right) \\
\text { Seed rate }\left(\mathrm{kg} \mathrm{ha}^{-1}\right)\end{array}$}} & \multirow[t]{3}{*}{ Mean } \\
\hline & & & & & \\
\hline & & 90 & 110 & 130 & \\
\hline \multirow[t]{4}{*}{ 2005-06 } & BG 1053 & 1439 & 1667 & 1480 & 1529 \\
\hline & GLK 21143 & 1118 & 1375 & 1190 & 1227 \\
\hline & GLK 22117 & 1501 & 1441 & 1315 & 1419 \\
\hline & Mean & 1353 & 1494 & 1328 & \\
\hline \multirow[t]{5}{*}{ 2006-07 } & BG 1053 & 1244 & 1320 & 1158 & 1241 \\
\hline & GLK 22117 & 1287 & 1385 & 1244 & 1306 \\
\hline & GLK 23008 & 925 & 963 & 1104 & 997 \\
\hline & GLK 23035 & 790 & 1093 & 1277 & 1053 \\
\hline & Mean & 1062 & 1190 & 1196 & \\
\hline \multirow[t]{5}{*}{ 2007-08 } & BG 1053 & 1160 & 1790 & 1697 & 1549 \\
\hline & GLK 24092 & 1250 & 1960 & 1867 & 1692 \\
\hline & GLK 25132 & 1111 & 1621 & 1605 & 1446 \\
\hline & Mean & 1174 & 1790 & 1723 & \\
\hline & Overall mean & 1196 & 1491 & 1415 & \\
\hline \multicolumn{2}{|c|}{ CD $5 \%$} & 2005-06 & 2006-07 & 2007-08 & \\
\hline \multicolumn{2}{|c|}{ Genotypes (G) } & 85 & 90 & 169 & \\
\hline \multirow{2}{*}{\multicolumn{2}{|c|}{ Seed rates (S) }} & 85 & 78 & 169 & \\
\hline $\mathrm{G} \times \mathrm{S}$ interaction & & 148 & 157 & NS & \\
\hline
\end{tabular}

Table.7 Gross returns of kabuli chickpea genotypes as influenced by seed rates

\begin{tabular}{|c|c|c|c|c|c|}
\hline \multirow[t]{3}{*}{ Year } & \multirow[t]{3}{*}{ Genotype } & \multirow{2}{*}{\multicolumn{3}{|c|}{$\begin{array}{l}\text { Gross returns }\left(\mathrm{Rs} \mathrm{ha}^{-1}\right) \\
\text { Seed rate }\left(\mathrm{kg} \mathrm{ha}^{-1}\right)\end{array}$}} & \multirow[t]{3}{*}{ Mean } \\
\hline & & & & & \\
\hline & & 90 & 110 & 130 & \\
\hline \multirow[t]{4}{*}{ 2005-06 } & BG 1053 & 71950 & 83350 & 74000 & 76433 \\
\hline & GLK 21143 & 55900 & 68750 & 59500 & 61383 \\
\hline & GLK 22117 & 75050 & 72050 & 65750 & 70950 \\
\hline & Mean & 67650 & 74700 & 66400 & \\
\hline \multirow[t]{5}{*}{ 2006-07 } & BG 1053 & 62200 & 66000 & 57900 & 62033 \\
\hline & GLK 22117 & 64350 & 69250 & 62200 & 65267 \\
\hline & GLK 23008 & 46250 & 48150 & 55200 & 49867 \\
\hline & GLK 23035 & 39500 & 54650 & 63850 & 52667 \\
\hline & Mean & 53100 & 59500 & 59800 & \\
\hline \multirow[t]{5}{*}{ 2007-08 } & BG 1053 & 58000 & 89500 & 84850 & 77450 \\
\hline & GLK 24092 & 62500 & 98000 & 93350 & 84617 \\
\hline & GLK 25132 & 55550 & 81050 & 80250 & 72283 \\
\hline & Mean & 58700 & 89500 & 86150 & \\
\hline & Overall mean & 59800 & 74550 & 70750 & \\
\hline
\end{tabular}


Table.8 Net returns of kabuli chickpea genotypes as influenced by seed rates

\begin{tabular}{llcccc}
\hline Year & Genotype & \multicolumn{3}{c}{ Net returns $\left(\mathrm{Rs} \mathrm{ha}^{-1}\right)$} & \multirow{2}{*}{ Mean } \\
\cline { 3 - 4 } & & \multicolumn{3}{c}{ Seed rate $\left(\mathrm{kg} \mathrm{ha}^{-1}\right)$} & \\
\cline { 3 - 5 } & & 90 & 110 & 130 & \\
\hline \multirow{2}{*}{$2005-06$} & BG 1053 & 56750 & 66550 & 55600 & 59633 \\
& GLK 21143 & 40700 & 51950 & 41100 & 44583 \\
& GLK 22117 & 59850 & 55250 & 47350 & 54150 \\
& Mean & 52450 & 57900 & 48000 & \\
& BG 1053 & 47000 & 49200 & 39500 & 45233 \\
& GLK 22117 & 49150 & 52450 & 43800 & 48467 \\
& GLK 23008 & 31050 & 31350 & 36800 & 33067 \\
& GLK 23035 & 24300 & 37850 & 45450 & 35867 \\
& Mean & 37900 & 42700 & 41400 & \\
& BG 1053 & 42800 & 72700 & 66450 & 60650 \\
& GLK 24092 & 47300 & 81200 & 74950 & 67817 \\
& GLK 25132 & 40350 & 64250 & 61850 & 55483 \\
& Mean & 43500 & 72700 & 67750 & \\
\hline & Overall mean & 44600 & 57750 & 52350 & \\
\hline
\end{tabular}

Table.9 Benefit:cost ratio of kabuli chickpea genotypes as influenced by seed rates

\begin{tabular}{|c|c|c|c|c|c|}
\hline \multirow[t]{3}{*}{ Year } & \multirow[t]{3}{*}{ Genotype } & \multicolumn{3}{|c|}{ B:C ratio } & \multirow[t]{3}{*}{ Mean } \\
\hline & & \multicolumn{3}{|c|}{ Seed rate $\left(\mathrm{kg} \mathrm{ha}^{-1}\right)$} & \\
\hline & & 90 & 110 & 130 & \\
\hline \multirow[t]{4}{*}{ 2005-06 } & BG 1053 & 4.73 & 4.96 & 4.02 & 4.57 \\
\hline & GLK 21143 & 3.68 & 4.09 & 3.23 & 3.67 \\
\hline & GLK 22117 & 4.94 & 4.29 & 3.57 & 4.27 \\
\hline & Mean & 4.45 & 4.45 & 3.61 & \\
\hline \multirow[t]{5}{*}{ 2006-07 } & BG 1053 & 4.09 & 3.93 & 3.15 & 3.72 \\
\hline & GLK 22117 & 4.23 & 4.12 & 3.38 & 3.91 \\
\hline & GLK 23008 & 3.04 & 2.87 & 3.00 & 2.97 \\
\hline & GLK 23035 & 2.60 & 3.25 & 3.47 & 3.11 \\
\hline & Mean & 3.49 & 3.54 & 3.25 & \\
\hline \multirow[t]{5}{*}{$2007-08$} & BG 1053 & 3.82 & 5.33 & 4.61 & 4.59 \\
\hline & GLK 24092 & 4.11 & 5.83 & 5.07 & 5.00 \\
\hline & GLK 25132 & 3.65 & 4.82 & 4.36 & 4.28 \\
\hline & Mean & 3.86 & 5.33 & 4.68 & \\
\hline & Overall mean & 3.93 & 4.44 & 3.85 & \\
\hline
\end{tabular}


Table.10 Days taken to 50\% flowering and maturity by different genotypes of kabuli chickpea

\begin{tabular}{llcc}
\hline Year & Genotype & \multicolumn{2}{c}{ Days taken to } \\
\cline { 3 - 4 } & & 50\% flowering & Maturity \\
\hline $2005-06$ & BG 1053 & 88 & 146 \\
& GLK 21143 & 95 & 152 \\
$2006-07$ & GLK 22117 & 90 & 148 \\
& BG 1053 & 108 & 163 \\
& GLK 22117 & 106 & 156 \\
& GLK 23008 & 110 & 161 \\
$2007-08$ & GLK 23035 & 109 & 158 \\
& BG 1053 & 100 & 139 \\
& GLK 24092 & 103 & 144 \\
& GLK 25132 & 98 & 136 \\
\hline
\end{tabular}

Fig.1 Weekly mean minimum and maximum temperatures recorded at the Meteorological Observatory of the Punjab Agricultural University, Ludhiana, India

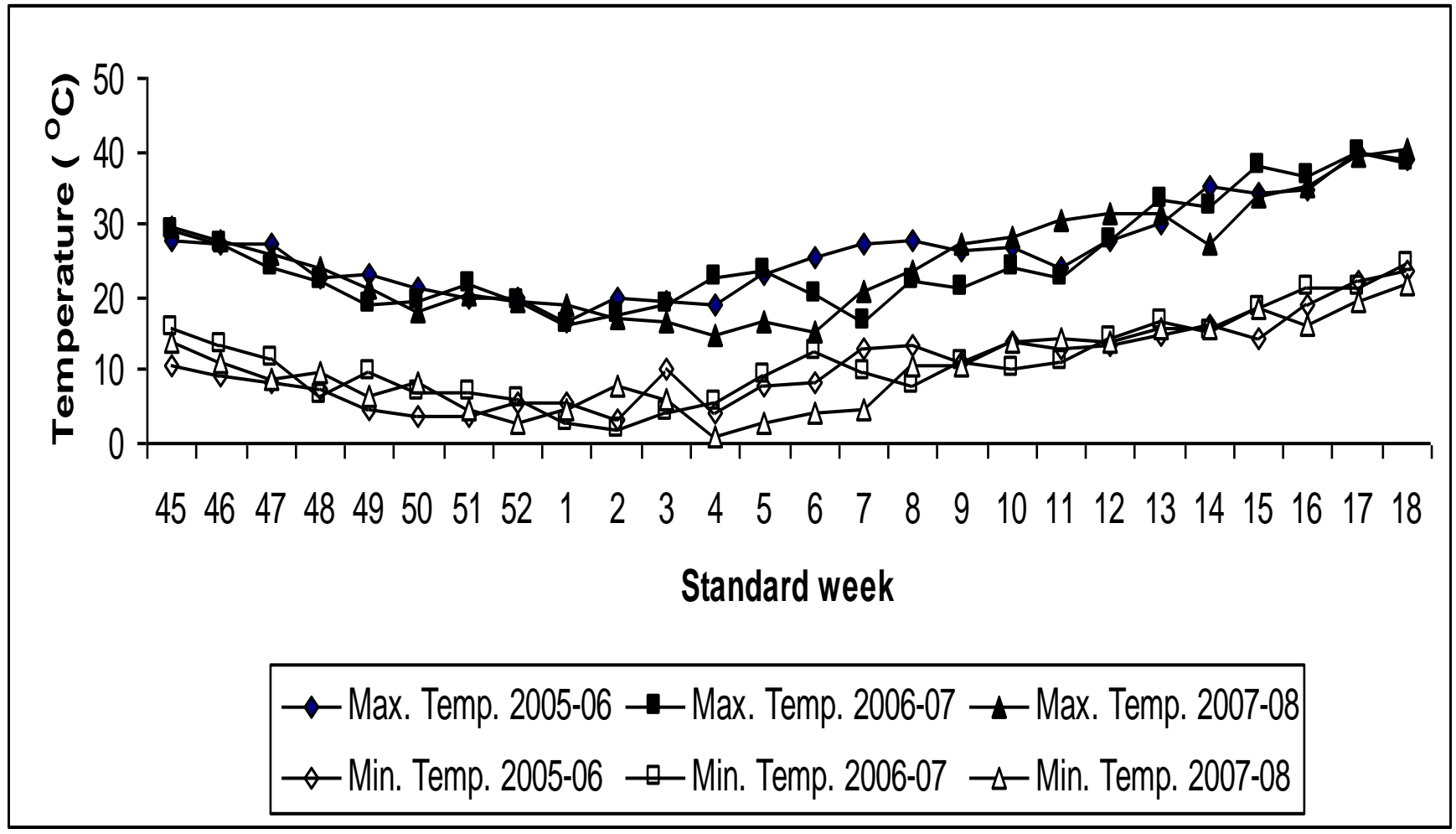


In chickpea, Ascochyta blight, Botrytis grey mould and Fusarium wilt are the serious diseases. In the present studies, no occurrence of any of these diseases was observed. This could be due to resistance in the tested genotypes against all these diseases or the occurrence of Ascochyta blight was avoided due to the protective spray with a fungicide Captaf. Chickpea genotypes do vary in resistance to Ascochyta blight (Gan et al., 2003a).

In kabuli chickpea, in a breeding programme, generally the main objective is not only to develop high yielding disease resistance genotypes but also those genotypes which have bold seeds, as bold seeded chickpeas fetch higher market price. However, boldseeded genotypes may not always give higher grain yields, because the genotypes having higher 100-seed weight generally have lower number of pods plant ${ }^{-1}$ or seeds pod $^{-1}$ (Liu et al., 2003; Singh and Sekhon 2006; Sheoran et al., 2008) as also observed in the present study (Tables 3-5). Kumar et al., (2008) also reported higher grain yield of genotype BG 1053 with $100 \mathrm{~kg}$ ha $^{-1}$ seed rate than with 75 or $125 \mathrm{~kg} \mathrm{ha}^{-1}$.

In conclusion, in northern Indian states, especially Punjab, Haryana and western Uttar Pradesh, underground water is going deep at an alarming rate. There is a need to shift from high water requiring cropping system of ricewheat to some other low water requiring crops such as chickpea during winter season. Kabuli chickpea, due to its high market price, can economically compete well with wheat. For obtaining high yield as well as net returns a seed rate of $110 \mathrm{~kg} \mathrm{ha}^{-1}$ should be used. BG 1053, GLK 22117, GLK 24092 and GLK 25132 are promising genotypes.

\section{Acknowledgement}

The authors are thankful to the Punjab Agricultural University, Ludhiana, India for providing funds and other facilities for conducting these trials.

\section{References}

Aggarwal, N., Ram, H., Singh, G. and Sharma, P. 2016. Effect of plant density and nutrient management on symbiotic activity and productivity of extra large seeded kabuli chickpea (Cicer arietinum L.) genotypes. Progressive Res. An Int. J., 11:19-23.

Ayaz, S., McKenzie, B.A., Hill, G.D. and McNeil, D.L. 2004a. Variability in yield of four grain legume species in a subhumid temperate environment I. Yields and harvest index. The J. Agri. Sci., 142: 9-19.

Ayaz, S., McKenzie, B.A., Hill, G.D. and McNeil, D.L. 2004b. Variability in yield of four grain legume species in a subhumid temperate environment. II. Yield components, The J. Agri. Sci., 142: 21-28.

Ayaz, S., McKenzie, B.A., McNeil, D.L. and Hill, G.D. 2004c. Light interception and utilization of four grain legumes sown at different plant populations and depths. The J. Agri. Sci., 142: 297-308.

Bavalgave, V.G., Gokhale, D.N., Waghmare, M.S. and Jadhav, P.J. 2009. Growth and yield of Kabuli chickpea varieties as influenced by different spacing. Int. J. Agri. Sci., 5: 202-204.

Chaudhary, B.M., Patel, J.J. and Delvadia, D.R. 2005. Effect of weed management practices and seed rates on weeds and yield of chickpea. Indian J. Weed Sci., 37: 271-272.

FAOSTAT. 2017. http://www.fao.org/faostat/en/\#data/QC.

Gan, Y.T., Liu, P.H. and McDonald, C. 2003a. Severity of Ascochyta blight in relation to leaf type in chickpea. Crop Sci., 43: 2291-2294.

Gan, Y.T., Liu, P.H., Stevenson, F.C. and 
McDonald, C.L. 2003c. Interrelationships among yield components of chickpea in semiarid environments. Canadian J. Plant Sci., 83: 759-767.

Gan, Y.T., Miller, P.R., McConkey, B.G., Zentner, R.P., Liu, P.H. and McDonald, C.L. 2003b. Optimum plant population density for chickpea and dry pea in a semiarid environment. Canadian $J$. Plant Sci., 83: 1-9.

Hira, G.S. 2009. Water management in northern states and the food security of India. J. Crop Improvement, 23: 136157.

Khan, S.A., Islam, N., Biswas, M., Akhter, A.K.M.H. and Sardar, N.A. 1999. Effect of seeding depth and seed rate on the growth and yield of chickpea (Cicer arietinum L.). Bangladesh J. Scientific and Industrial Res., 34: 248-253.

Kibe, A.M. and Kamithi, D.K. 2007. Production potential of desi chickpea grown under various nitrogen and planting densities at Naivasha. Agri. J., 2: $520-525$.

Kumar, D., Verma, R.N. and Tripathi, H.N. 2009. Productivity and economics of breeder seed of chickpea (Cicer arietinum L.) as affected by sowing methods, seed rates and sulphur levels. Res. Crops, 10: 42-47.

Kumar, S., Singh, R.V. and Pal, M.K. 2008. Influence of plant density, spatial arrangement and weed management on weeds of chickpea (Cicer arietinum L.) in western central plains. Progressive Agri., 8: 278-280.

Kumar, A., Reena, Nandan, B., Kumar, J. and Jamwal, B.S. 2008. Effect of phosphorus and seed rate on growth and productivity of large seeded kabuli chickpea in subtropical kandi areas of Jammu and Kashmir. J. Food Legumes, 21: 231-233.

Liu, P..H, Gan, Y.T., Warkentin, T. and
McDonald, C. 2003. Morphological plasticity of chickpea in a semiarid environment. Crop Sci., 43: 426-429.

Mansur, C.P., Palled, Y.B., Halikatti, S.I., Salimath, P.M. and Chetti, M.B. 2009. Effect of plant densities and phosphorus levels on seed yield and protein content of Kabuli chickpea genotypes Karnataka J. Agri. Sci., 22: 267-270.

Nagarajaiah, K.M., Palled, Y.B., Patil, B.N. and Khot, A.B. 2005. Response of chickpea varieties to seed rate and time of sowing under late sown conditions in Malaprabha Command Area. Karnataka J. Agri. Sci., 18: 609-612.

PAU. 2016. Package of practices for rabi crops of Punjab, 2016-17. Punjab Agricultural University, Ludhiana, India.

Sekhon, H.S. and Singh, G. 2008. Response of kabuli chickpea (Cicer arietinum) genotypes to seed rates. Indian J. Agri. Sci., 78: 641-642.

Sekhon, H.S., Singh, G. and Bains, T.S. 2002. Influence of time of sowing and fertilizer $\mathrm{N}$ on chickpea (Cicer arietinum L.). Environ. Ecol., 20: 450454.

Sekhon, H.S., Singh, G., Chandi, J.S., Sardana, V., Singh, I. and Ram, H. 2004. Effect of planting methods and irrigation on the productivity of chickpea sown after rice. Int. Chickpea and Pigeonpea Newslett., 11: 22-25.

Sekhon, H.S., Singh, G., Gill, A.S., Gumber, R.K., Kumar, K., Singh, D. and Randhawa, A.S. 1994. Influence of environment on chickpea yield. Int. Chickpea and Pigeonpea Newslett., 1: 15-16.

Sekhon, H.S., Singh, G., Randhawa AS.,. Sandhu, J.S., Gumber, R.K., Singh, S.J. and Brar, A.P.S. 2001. Effect of phosphorus on the productivity of kabuli and desi chickpea (Cicer arietinum L.) genotypes. Environ. Ecol., 
19: 533-536.

Sharma, P. and Singh, G. 2013. Cold tolerance during reproductive growth of chickpea (Cicer arietinum): Genetic variation in flower production and pod set. Vegetos, 26: 223-228.

Sheoran, P., Sardana, V. and Singh, S. 2008. Effect of sowing dates and seed rates on productivity of chickpea cultivars under dryland conditions in Shiwalik foothills of Punjab. J. Food Legumes, 21: 43-45.

Singh, G. and Sekhon, H.S. 2006. Effect of row spacing and seed rate on the growth and grain yield of desi chickpea (Cicer arietinum) genotypes. Indian J. Agri. Sci., 76: 375-376.

Singh, G., Ram, H., Aggarwal, N. and Turner, N.C. 2016. Irrigation of chickpea (Cicer arietinum L.) increases yield but not water productivity. Experimental Agri., 52: 1-13.

Singh, G., Sekhon, H.S. and Sharma, P. 2011. Effect of irrigation and biofertilizer on water use, nodulation, growth and yield of chickpea (Cicer arietinum L.). Arch. Agronomy and Soil Sci., 57: 715-726.

Singh, G. 2016. Irrigation, seed rate and phosphorus management in vegetable grain chickpea (Cicer arietinum). Bioinfolet, 13: 26-28.

Venkatachalapathi, V. and Saini, S.S. 2003. Influence of seed rate and spatial arrangement on growth and yield of chickpea under late sown condition. Annals of Agri. Res, 24: 693-694.

Venkatachalapathi, V., Saini, S.S. and Singh, B.P. 2004. Yield of chickpea cultivar HC 1 as influenced by seed rate and spatial arrangement under late sown condition. Haryana J. Agron., 20: 100101.

Virk, H.K., Singh, G. and Sekhon, H.S. 2005. Effect of time of sowing on the productivity of chickpea (Cicer arietinum L.) varieties. J. Res. Punjab Agri. Univ., 42: 148-149.

\section{How to cite this article:}

Guriqbal Singh, Hari Ram and Navneet Aggarwal. 2017. Growth, Productivity and Economics of Kabuli Chickpea (Cicer arietinum L.) Genotypes in Response to Seed Rate in Northern India. Int.J.Curr.Microbiol.App.Sci. 6(7): 3917-3930. doi: https://doi.org/10.20546/ijcmas.2017.607.404 